\title{
Manages and Management of Nursing Care in Primary Attention: an Integrative Review of the Literature
}

Gyl Dayara Alves Carvalho1, Sérgio Ribeiro Santos², Maria Bernadete de Sousa Costa², Leila de Cássia Tavares da Fônseca ${ }^{3}$, Michelle Alves de Carvalho4, Saemmy Grasiely Estrela de Albuquerque ${ }^{5}$, Tainara Barbosa Nunes ${ }^{6}$, Liliane Agnelly dos Anjos Marreiro7, Julianne Guimarães Oliveira Soares ${ }^{8}$, Bruna Lopes da Silva ${ }^{9}$

\section{Abstract}

Objective: This is an integrative review of the literature that aimed to characterize the scientific production of the last ten years of management and management of nursing care in primary care and describe the practice of this management. The search of the material took place in May and June 2014 in the databases SCIELO, LACHC and MEDLINE NDB considering the terms: Management; care management; Health Management; Nursing and Primary Health Care, so that 16 articles were included in the sample selected. The characterization of the studies pointed out the year 2010 with the largest quantity of sample publications; the Cuban Journal of Enfermería was the one that got more than one publication; 10 studies are presented in Portuguese, three in English and three in Spanish. Three themes were highlighted for discussion: management practice and management of nursing care in Primary Care; Skills and nursing skills; and Challenges faced. We emphasize the importance of managerial activities of the nursing organization and qualification of care and transformation of health in primary care, demonstrating is necessary to build quality indicators; democratization of organizational behavior; systematization of assistance; best training and continuing education of professionals.
1 Nurse. Master in Nursing from the Federal University of Paraíba. João Pessoa, *

2 Nurse. PhD in Nursing. Department of Clinical Nursing at the Federal University of Paraíba (DENC/UFPB). João Pessoa, *

3 Nurse. PhD student in Nursing. Department of Clinical Nursing at the Federal University of Paraíba (DENC/UFPB). João Pessoa, *

4 Nurse. Family and Community Health Specialist. João Pessoa, *

5 Nurse. Master's Graduate Program in Nursing at the Federal University of Paraíba (PPGEnf/UFPB). João Pessoa, *

6 Family Health Specialist. Nurse of Family Health Strategy in Guarabira, *

7 Nurse. Specialist in Occupational Health Nursing. João Pessoa, *

8 Psychologist. Specialist in Cognitive, Behavioral Therapy. João Pessoa, *.

9 Nurse. Master in Health and Decision Models from the Federal University of Paraíba. João Pessoa *

\section{Contact information:}

Gyl Dayara Alves Carvalho.

”'gyl_dayara@hotmail.com

Keywords

Management; Health

Management; Nursing Care;

Primary Health Care.
Health Familiar Program (HFP) foundation, in 1994, it is searched the improvement of the population's health indicators and the re-orga- 
nization of the Basic Care of the country, in a way that the family health team is responsible for developing actions of promotion, prevention, heal and rehabilitation of the individuals' health [1].

As the coordinator of the others attention levels in the care network, the primary care shall approach the main problems of the community, aiming always for the problem-solver and holistic assistance providence, which promotes the population welfare [2].

Conducting those actions, the nurse is responsible for developing the assistance planning with the others team's professionals, as well as to the users and the community in a general way, considering the context/ reality permeating each territory [1].

In this sense, the attendance quality has been more and more discussed and required from the professionals and health services, while the units' management shall answer those requests, characterized by a democratic, participative, competent and efficient practice [2].

Therefore, the management activities are a way to perform the main assistance objective, which is the care quality, with basis empowered by the integrality, ethics and the flexible and modern management [3], while was created the care management concept, which regards to this connection between the assistance and the management, aiming to carry out the attendance to the patient's needs, team and health institution [4].

Being the management a nurse's function, defined in the national curriculum guidelines, shall be seen as an indispensable tool to the development and qualification of the daily activities, as well as the attendance to the HUS demands [5].

Although having few articulated dimensions, management and care are important elements in the nurse's work, emerging the necessity to be done together, without forget the focus which shall always the user and the spread and good care conduction [6].
Thereby, the care management activities include actions performed systematically and articulately, through the direct and indirect care, practical and sensitive, for the integral and quality assistance [7].

However, many professionals still have difficulties viewing the importance of the management activities and the conduction of the management care, seeing as relevant only the activities performed directly with the patient, without understand the complementarily in the indirect actions and care organization [8, 9].

The study describe that health unit management many times is reduced to the simple administration of human resources and materials regarding the fulfillment and attendance to the program and politics demandsestablished; but the effective management reflects in optimization of results and positives impacts in the life quality and population health; requiring different knowledge by the professionals [10].

In this sense, knowing that the primary attention, while an entrance door is responsible for big part of the health assistance demand, include a relevant contingent of professionals and, in special, of nurses, showing itself, so, as an attention level which needs improvement of the management actions and management care, aiming to attend the new requests of the society, of the politics and the health as a whole $[6,11]$.

The management shall be seen in the perspective of a daily Project of changes; the managers shall be seen in the perspective of a daily change Project, aiming to attend the real populations' needs and that it may be turned to the integral assistance. In that way, it is expected to the nurse performs this role in a participative way, guided by the integration and articulation with the others actors and professionals who constitute the primarycare to the health [11].

To meet the perspectives and system health principles and users needs, it is necessary to this Professional equilibrium, dynamism and creativity overcoming limitations and found difficulties [2]. 
Under this look, this investigation's relevance is shown by the necessity to capture and disseminate the knowledge about the managers and management of the nursing care, indispensable to the care provision, in the sphere of the primarycare, resolute and qualified, having in mind that the nurse action in this assistance level interfere greatly in the final care which achieves the individuals; well as through the reduced quantitative study which discuss about the subject in the current literature, raising the debate importance and scientific production in this sphere.

Thereby, this study searched answers to the following research problems: How it is characterized the scientific production from the last ten years about managers and management of the nursing care in the primary attention?How does the literature describe the nurse management in the basic care? To that, the objective was to characterize the published studies in the last ten years about managers and management of the nursing care primary attention and describe how the nurse management who acts in the primary care occurs.

\section{Metodology}

This study consists of an integrative literature review, which is characterized by the rescue and summarization of pre-existing research, allowing the correlation of results obtained in different studies, in addition to highlighting the main features of the publications, providing a synthesis of knowledge and incorporation of the applicability of the results of significant studies in professional practice [12].

The questions that guided the development of this research were: What are the characteristics of the scientific production management and management of nursing care in primary care? As the literature describes this nursing management in primary care?

The proposed study follows a standardized script, consisting of six stages: preparation of research questions; establishment of the search strategy in the literature; selection studies based on inclusion criteria; critical reading, evaluation and categorization of content obtained; analysis and interpretation of results.

To set the publications that would make this integrative review, there was an online search, in databases: Scientific Electronic Library Online (SciELO), Latin American and Caribbean Health Sciences (LILACS), Nursing Database (BDENF) e Medical Literature Analysis and Retrieval System Online (MEDLINE).

The pursuit of material made in the months of May and June 2014, considering the following terms: Management; care management; Health Management; Nursing and Primary Health Care In order to restrict the sample, we used the Boolean operator and, together with the combinations of terms: Care and Nursing and Primary Health Care Management; Management and Nursing and Primary Health Care and Health Management and Nursing and Primary Health Care

For the selection of studies the following inclusion criteria were used: the publication was in the form of article; that present available in full text article was published between 2004 and 2013 and was in Portuguese, English or Spanish.

With respect to the exclusion criteria, they were rejected articles outside the specified time period, no studies available for free and in full, publications that were not in the form of article and those who, despite having the selected terms have not reached the focus of the proposed theme.

In order to organize the content obtained after the collection of the material, a frame was used with the following items: article title, year, journal name, purpose, mode of study, level of evidence and main contributions of each publication. When was conducted the assess of evidence level of the studies was considered the Melnyk rating and Fineout-Overholt13, Guided by seven levels: 1 systematic review or meta-analysis; 2 RCTs; 3 clinical trial 
without randomization; 4 cohort studies and casecontrol; 5- systematic review; 6 single descriptive or qualitative study and 7-opinion of authorities and/ or experts.

Data analysis was guided also by the translation and thorough reading of the studies and subsequent categorization and definition of thematic approaches that guided the discussion of the topic.

\section{Results}

The studies search in databases resulted in a total of 2,957 publications, so that 22 of them were not in the form of article; 1,175 were not included in the 2004-2013 period; and 1.066 were presented not available in its entirety; thereby resulting in a quantity of 601 articles under this initial search. To be eliminated repetitions and perform reading the abstracts, 75 studies were selected for reading in full, but only 16 were included in the sample selected with a view are understood by the objectives of this research. These steps are summarized in Figure 1.

Regarding the characterization of the selected studies, it is noted that the year 2010 had the highest quantity of sample publications, with five (31.3\%) studies; then the year 2012, with 4 trials (25\%); 2011 was responsible for the 3 studies (18.8\%); and the years 2009 and 2013 counted just 2 each study $(12.5 \%)$. It is important to note that there are no studies published between the years 2004 to 2008 to conform to the objectives of this investigation,

Figure 1: Steps covered in conducting the search and selection of studies.

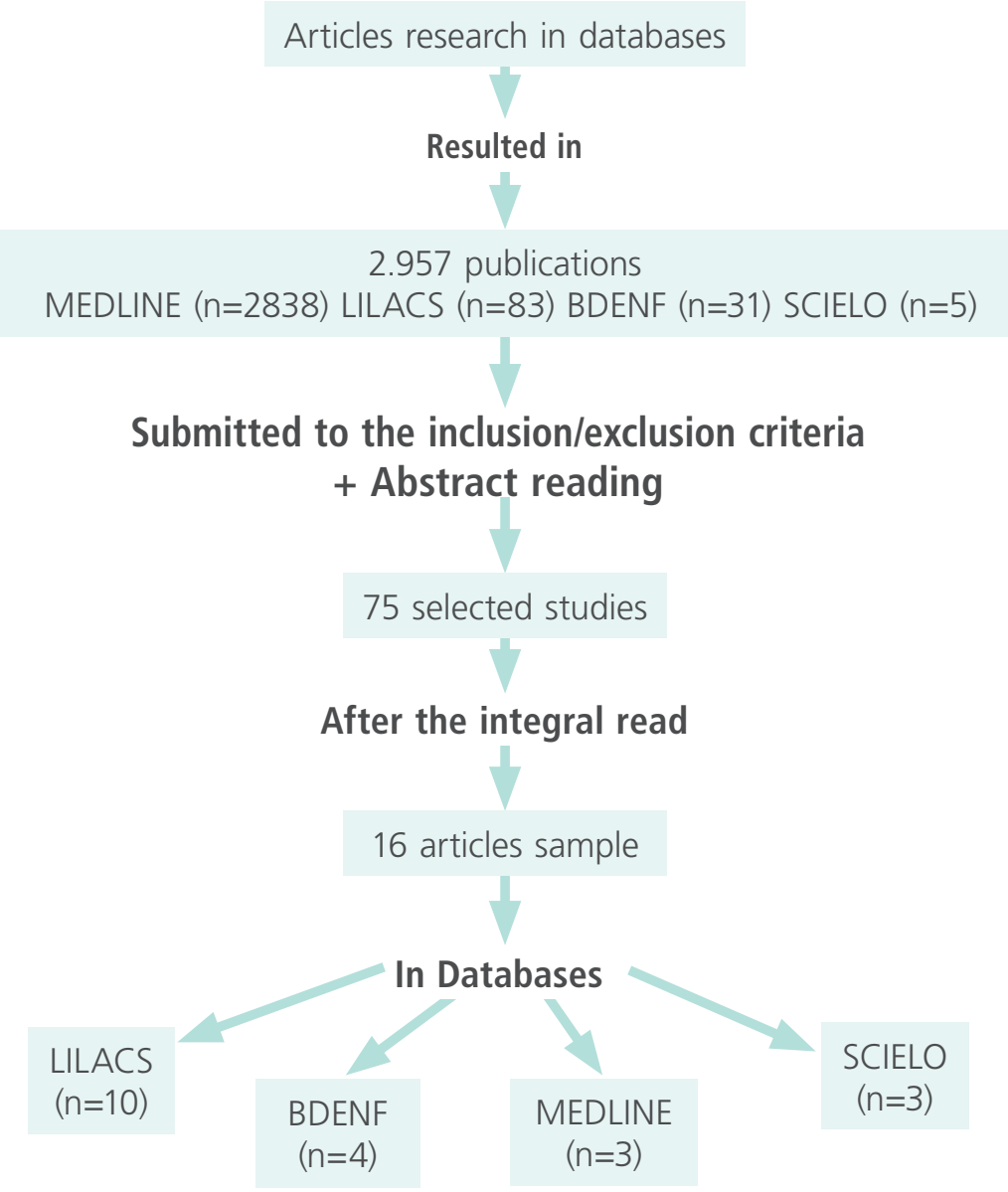

Source: Data extracted from the study. João Pessoa. Brazil, 2016. 
confirming the emergence of the theme and the small number of publications in the area.

As regards the periodic publications that emerged, they were quite diverse, whereas onlyin Revista Cubana de Enfermería the analysis was repeated studies, appearing 2 times (12.5\%); periodicals Revista de Enfermagem Referência, Annals of Family Medicine, Revista Gerencia y Politicas de Salud, Enfermería Global, UFSM Revista de Enfermagem, Revista de Enfermagem do Centro-OesteMineiro, Ciencia y Enfermería, Nursing Ethics, Iranian Journal of Nursing and Midwifery Research, Revista Brasileira de Enfermagem, Ciência \& Saúde Coletiva,
Texto\& Contexto Enfermagem, Ciência, Cuidado \& Saúde and Revista RENE was responsible for one study, representing $6.3 \%$ of the sample.

In the case of language studies, $10(62.5 \%)$ of them are presented in Portuguese, $3(18.8 \%)$ in English and 3 (18.8\%) in Spanish. Already for the quality of the scientific evidence on the subject, the vast majority of the studies ( $n=13$ ) were classified as level 6, noting only weak evidence.

Table 1 provides an overview of the publications in the sample used in this study and the main characteristics of the same.

Table 1. Distribution of articles between 2004 and 2013 that addressed managers and management at nursing care in primary care.

\begin{tabular}{|c|c|c|c|c|c|}
\hline Texto Contexto Enferm & Databases & $\begin{array}{l}\text { Publication } \\
\text { year }\end{array}$ & Periodic & Method & $\begin{array}{l}\text { Evidence } \\
\text { level }\end{array}$ \\
\hline $\begin{array}{l}\text { Conceptions of nurses about planning, } \\
\text { organization and nursing management in } \\
\text { primary care: an integrative review }\end{array}$ & SCIELO & 2013 & $\begin{array}{l}\text { Revista de Enfermagem } \\
\text { Referência }\end{array}$ & $\begin{array}{l}\text { Integrative } \\
\text { Revision }\end{array}$ & 5 \\
\hline $\begin{array}{l}\text { Improved outcomes in diabetes care for } \\
\text { rural African Americans }\end{array}$ & MEDLINE & 2013 & $\begin{array}{l}\text { Annals of Family } \\
\text { medicine }\end{array}$ & $\begin{array}{l}\text { Intervention } \\
\text { Study }\end{array}$ & 2 \\
\hline $\begin{array}{l}\text { Analysis of the managers work process } \\
\text { within the Family Health Strategy }\end{array}$ & LILACS & 2012 & $\begin{array}{l}\text { Rev. Gerenc. Politicas } \\
\text { Salud }\end{array}$ & Qualitative & 6 \\
\hline $\begin{array}{l}\text { Interview with managers as a pedagogical } \\
\text { method for managing in nursing: to know } \\
\text { to be }\end{array}$ & SCIELO & 2012 & Enfermería Global & Qualitative & 6 \\
\hline $\begin{array}{l}\text { The nursing management in the Family } \\
\text { Health Strategy }\end{array}$ & $\begin{array}{l}\text { LILACS } \\
\text { BDENF }\end{array}$ & 2012 & Revista RENE & Qualitative & 6 \\
\hline $\begin{array}{l}\text { The nurse and the family health } \\
\text { strategy: challenges in coordinating the } \\
\text { multidisciplinary team }\end{array}$ & LILACS & 2012 & $\begin{array}{l}\text { Ciência, Cuidado \& } \\
\text { Saúde }\end{array}$ & Qualitative & 6 \\
\hline $\begin{array}{l}\text { Nurses activities in the family health } \\
\text { strategy. }\end{array}$ & BDENF & 2011 & REUFSM & Qualitative & 6 \\
\hline $\begin{array}{l}\text { Management of integral attention center } \\
\text { to the elderly health }\end{array}$ & BDENF & 2011 & $\begin{array}{l}\text { Revista de Enfermagem } \\
\text { do Centro-Oeste Mineiro }\end{array}$ & Qualitative & 6 \\
\hline $\begin{array}{l}\text { Gestión del cuidado desde una } \\
\text { perspectiva transcultural }\end{array}$ & LILACS & 2011 & $\begin{array}{l}\text { Revista Cubana de } \\
\text { Enfermería }\end{array}$ & Quantitative & 6 \\
\hline $\begin{array}{l}\text { Enfermería em el rol de gestora de los } \\
\text { cuidados }\end{array}$ & LILACS & 2010 & Ciencia y enfermería & $\begin{array}{l}\text { Literature } \\
\text { Revision }\end{array}$ & 6 \\
\hline $\begin{array}{l}\text { Influencia de la gestión del cuidado en la } \\
\text { calidad de la atención de Salud }\end{array}$ & LILACS & 2010 & $\begin{array}{l}\text { Revista Cubana de } \\
\text { Enfermería }\end{array}$ & Documental & 6 \\
\hline $\begin{array}{l}\text { Ethical problems in nursing management: } \\
\text { The role of codes of ethics }\end{array}$ & MEDLINE & 2010 & Nursing Ethics & Quantitative & 6 \\
\hline
\end{tabular}




\begin{tabular}{|c|c|c|c|c|c|}
\hline Article headline & Databases & $\begin{array}{l}\text { Publication } \\
\text { year }\end{array}$ & Periodic & Method & $\begin{array}{l}\text { Evidence } \\
\text { level }\end{array}$ \\
\hline $\begin{array}{l}\text { Assessing the effect of community health } \\
\text { nursing care management at home on } \\
\text { war-worn soldiers' physical problems } \\
\text { suffering from spinal cord complications } \\
\text { (urinary infection, bedsore) }\end{array}$ & MEDLINE & 2010 & $\begin{array}{l}\text { Iran J Nurs Midwifery } \\
\text { Res }\end{array}$ & $\begin{array}{l}\text { Almost- } \\
\text { experimental } \\
\text { study }\end{array}$ & 4 \\
\hline $\begin{array}{l}\text { Nurse's performance analysis in the } \\
\text { management of basic health units }\end{array}$ & $\begin{array}{l}\text { LILACS } \\
\text { BDENF }\end{array}$ & 2010 & $\begin{array}{l}\text { Revista Brasileira de } \\
\text { Enfermagem }\end{array}$ & Qualitative & 6 \\
\hline $\begin{array}{l}\text { нealth care management: developed } \\
\text { competencies and difficulties encountered } \\
\text { in primary care }\end{array}$ & $\begin{array}{l}\text { SCIELO } \\
\text { LILACS }\end{array}$ & 2009 & Ciência \& Saúde Coletiva & Qualitative & 6 \\
\hline $\begin{array}{l}\text { The management work of nurses in Basic } \\
\text { Health Network }\end{array}$ & LILACS & 2009 & Texto Contexto Enferm & Quantitative & 6 \\
\hline
\end{tabular}

Source: Data extracted from the study. João Pessoa. Brazil, 2016

\section{Discussion}

After reading the material and subsequent data analysis, three themes were highlighted for discussion: management practice and management of nursing care in Primary Care; Skills and nursing skills; challenges faced.

\section{Topic category 1}

\section{Management practices in Nursing Primary} Care.

Both in Brazil and abroad, it discusses the professional nursing work has undergone several adaptations over time in order to meet the needs and perspectives of health services, which are constantly changing [14, 15]. Amid these changes, emerging debate and reflection on the managerial role of the nurse as coordinator of the healthcare team and must play this role in an interdisciplinary perspective, guided by collective effort, so that workers and users to build an assistance project that meets the population and the health service needs and at the same time uphold the integrity $[14,11]$.

Thus, the nurse as manager appears as mediator of the family health unit work process and management action performed at this location is characterized by the analysis of the work process, to identify and find solutions to problems and organization of practices with a view to achieving goals defined by planning [16].

Thereby, care management is directly related to the quality of health services, is characterized by the proper use of all the materials, personnel and technological resources necessary for the coordination and implementation of actions, with emphasis on the moral and professional values [15, 14].

Therefore, the authors state that the nurse should act turning to the reality and needs of the population assisted by the health unit, with emphasis on prevention, health promotion and protection, so that the knowledge of the territory and the context of health- local disease are by their responsibility of professional and integral part of the work process $[1,17]$, as well as form the basis for care planning and management of care.

Thus, the work of nurses in the care basic front junction of management and care dimensions is performed through the production of care and therapeutic projects, population monitoring of the area and their health status, supervision of nursing staff and health service involved to provide care [18].

Research conducted in southern Rio Grande do Sul region pointed as management actions descri- 
bed by the nurses of basic units, the coordination of the health team; the achievement/participation in team meetings; the pursuit and promotion of training and continuing education for the Community Health Agents (CHA) And technical professionals as well as for themselves and doctors; filling activity reports; the management unit; supervision of $\mathrm{CHA}$; systematization and care planning; management of material resources and technical responsibility with the class council. Such activities are performed together to care practices, such as consultations, procedures and sample collection; notifications; visits and home care; coordination of operative groups in the community; health education in the community [1]. This set of activities make up the care management at this level of care.

Data collected with basic unit managers in Caxias do Sul (RS) showed that $82.7 \%$ of them perform frequently epidemiological surveillance; $55.2 \%$ are involved in the practice of health surveillance; $93.1 \%$ work with government programs, taking action in the health of children, elderly, woman, teenager, etc; $89.7 \%$ are responsible for programming and control of spontaneous demand, including here the reception and humanization of the waiting room; and $79.3 \%$ said they had the assignment to manage materials, medicines and supplies [2]. This demonstrates the breadth of management actions and management of care.

In Goiânia (GO), the authors reported that in a day's work, $61.4 \%$ of the activities developed by nurse managers of primary health care network, are essentially management; and $38.6 \%$ of the shares and services are characterized as management of the care provided, including, here, health education in the community, training of health staff, providing outpatient care and emergency care [11].

International studies show the relevance of care management in primary care, while one of them shows the reduction of blood glucose, blood pressure and cholesterol in African American diabetics, residents in rural areas with high poverty rate, ob- tained through remaking the provided care, with emphasis on education and psychosocial support, interdisciplinary work and better use of resources even in the face of precarious situations. The situation is put that care managers were a nurse, a dietician and a pharmacist [19].

Research has brought the benefits of nursing care management in community health in the proper identification of problems and injuries and minimizes complications in Iranian soldiers with spinal cord sequel resulting from the war. In this sense, the study participants showed a decrease from $100 \%$ to $7.7 \%$ in the occurrence of bedsore; $23.1 \%$ did not have more urinary tract infection; and conditions were identified that required special attention, as the darkening of the urine, the presence of muscle spasms, fever, chills; all these important condition presented by patients who were only seen after management intervention of nursing care, marked by the continuity of care and periodic evaluation and use of vital statistics in the care deliverery [20].

Thereby, we see that the management actions are essential to the good performance of the service as a whole and part of the nurse practice engaged in primary care, encompassing the provision of community and/or primary care, considering that the PSF still is not a global reality; and these actions summarized in three aspects, people management, process management and focus management on the user, emphasizing the need to value the joint work of professionals, but also the partnership of users and explicitness of their real needs, while guiding practices and target of all these processes [21, 22].

\section{Topic category 2 Nursing skills and abilities}

Authors state that the nurses who work in primary care has the role of mediating relations between the assisted community and the political sphere, should be aware of the importance of this award, as, to 
gather information from different sectors and turn them into knowledge It brings with it the possibility of providing changes to the population's health and quality of life [23].

In this sense, it is argued that the nurse manager takes along his team, the responsibility of caring for individuals, families, professionals, health unit, the territory and the community; should be aware of, among other things, to interpersonal relationships and subjectivities that involve human beings, with a view to completeness and minimizing conflicts [17, 2]. Study also highlights that the appreciation of the socio-cultural aspects of individuals are indispensable care management, while the health sphere can not be addressed separately from the diversity and multidimensionality of the social, failing to get a distorted view of reality [24].

In this way, it puts the manageability of a health unit requires balance of this professional front to overcome the limitations presented by the service, paying termination assistance and in accordance to the principles of the SUS; still requires managerial competence; determination against the pursuit of established goals; personality and interpersonal skills in order to motivate the team and get the satisfaction of users [2].

This interpersonal competence, in turn, is much discussed and points to skills related to proper communication, creativity and innovation, selfawareness and perception, as well as the exercise of the relationship with each other, their emotions and affectivity. The practice of the team dialogue still requires harmony among its members. Aspects such as these reflect a transparent and in a safe practice $[11,15,2]$.

Another prominent element relates to the capacity planning of the actions effectively, which must always be linked to improving the health of the population, as well as social participation in order to strengthen the effectiveness of the processes [23, 1]. Through this planning, characterized by being participatory, the nurse must also motivate team members, being flexible and open to dialogue; organize activities and make everyone seek common goals, transforming ideas into actions $[23,15]$.

Thus, the professional must be prepared for the development of care management and all aspects involved, corresponding to a qualified front care users and their needs, and against the company that commissioned him this paper [25]. Therefore, you should use knowledge and practices in overcoming obstacles, physical space optimization and material resources, coordination of activities, relationship management, and adaptation of working hours in order to maintain the standard of expected quality and ensure the right to health [10].

In this context, the technical and scientific knowledge are indispensable, arising from the academic and continuing throughout professional practice, also highlighting the administrative knowledge and ethics as the basis of all actions; all these use the act of nurses of primary care in their daily work $[23,26,15]$.

Among other skills and outstanding skills is leadership and unit management, resilience, professional autonomy to accomplish tasks and practice of extended clinic, consisting of soft and hard technologies, against the better targeting of actions and services of process work to care centered on the individual and not the disease [2, 26, 23, 27].

\section{Topic category 3. Faced challenges}

It is seen that the management work in the FHS demand nurses committed to the transformation of health, presenting open to knowledge and knowledge sharing; however, there are several difficulties in day-to-day of this professional, you see between technical and care demands [26, 27].

Among the most discussed impasses has the academic training of nurses, as well as the improvement of the professional to the administrative demands/ management throughout his career, while the development of skills and knowledge is required from 
the gym, lasting throughout professional life. However authors state that schools are still very focused on the technical skills of nursing practice, leaving the detailed management training $[23,11,1]$.

Thus, nurses see themselves unprepared to care management, which ends up being developed empirically, without scientific support base strengthened and/or knowledge of instruments that could direct them. This situation certainly affects the planning of care and quality of care that reaches the users of the service [26].

In parallel with little training, are described several other limiting issues of care management, such as lack of care planning, nurse communication difficulties with the other members of staff, insufficient number of professional activities burden on the nurse and consequent lack of time for greater commitment in the face of perceived as non-emergency activities, excessive bureaucracy and necessity of meeting targets, so that the work done in primary care is seen much more quantitatively than the quality of care provided, lack of management support, the deficiency of material and financial resources, inadequate physical infrastructure, difficulties in working with hard technology (e.g. computer) [23, 26, 1, 22, 2].

Study conducted with 205 nursing managers, 78 nurses in primary care, in Finland, in order to identify the ethical problems present in the work of these professionals, corroborates some of these difficulties, pointing out the lack of human resources, lack the ethical, as well as training on the basis of the decision-making process in nursing management as issues that require significant changes in order to obtain the qualification of assistance to health, still puts elements such as organizational culture, acts and professional skills as key factors for effective care [28].

In this sense, there is a clear need to build a more focused nursing management qualification of care and transformation of health, which requires, among others, the construction of quality indicators to be pursued by the team work, the greater democratization of behavior organizational and desired goals; the systematization of care, based on ratings of diagnoses and nursing interventions, allowing for better organization of time and resources, and recognition of nurses' work; continuing education aimed at managing the FHS, for the seizure of instruments necessary for the best level of care will individuals and families; academic training to enable the professional preparation with assistance not only skills but also managerial and interpersonal; and the expansion of nurses discussion spaces on the coordination of USF, their experiences and challenges in order to allow the continued development of this to health care model $[15,23,26]$.

\section{Final Considerations}

Management and care are presented as main activities of the nurse's work, whereas in practice both complement and contribute to the fulfillment of the other.

In this sense, the results of this review identified the importance of management and nursing care management in the context of primary health care, which stands out for its peculiar characteristics of assistance aimed at the care to individuals and families in their context life, so that the management activities are seen as indispensable elements of the organization and quality of care and care provided at this level of attention. However, the literature shows that there are many difficulties and challenges experienced by nurses in the performance of these tasks, since they do not have adequate preparation and various are the skills and functions required of this professional, you see overloaded.

In this sense it is necessary to strengthen the division of labor and interdisciplinary, to each professional grasp the true value of teamwork; stimulate teaching and research in management in health and nursing, so that professionals, with emphasis on nurses leave the gym with a base made about 
the tools necessary for their good performance and extend the discussion spaces on the positive and negative experiences that these professionals spend on a daily basis, which are certainly essential to the construction of knowledge about the theme and the performance better and better professionals, which will reflect a systematic attention and meets the real needs of individuals.

\section{References}

1. Junior DDAB, Heck RM, Ceolin T, Viegas CRS. Atividades Gerenciais do Enfermeiro na Estratégia de Saúde da Família. RevEnferm UFSM 2011 [acesso em 2015 dez 30]; v. 1, n.1, p. 4150. Disponível em: <http://cascavel.ufsm.br/revistas/ojs-2.2.2/ index.php/reufsm/article/view/1841>.

2. Fernandes LCL, Machado RZ, Anschau GO. Gerência de serviços de saúde: competências desenvolvidas e dificuldades encontradas na atenção básica. Ciênc Saúde Coletiva2009 [acesso em 2016 jan 10]; v. 14, n. 5, p. 1541-1552. Disponível em: <http://www.redalyc.org/articulo.oa?id=63012430025>.

3. Jonas $L T$, Rodrigues $H C$, Resck ZMR. A função gerencial do enfermeiro na Estratégia saúde da Família: limites e possibilidades. Rev APS 2011 [acesso em 2016 jan 10]; v. 14, n. 1, p. 28-38. Disponível em: <http://aps.ufjf.emnuvens.com.br/ aps/article/view/977>.

4. Santos JLG, Prochnow AG, Lima SBS, Leite JL, Erdmann AL. Concepções de comunicação na gerência de Enfermagem Hospitalar entre enfermeiros gerentes de um hospital universitário. Rev Esc Enferm USP2011 [acesso em 2015 nov 25]; v. 45, n. 4, p. 959-965.

5. Ministério da Educação (BRASIL), Conselho Nacional de Educação. Parecer do CNE/CES n¹133 de 7 de agosto de 2001. Dispõe sobre as Diretrizes Curriculares Nacionais dos Cursos de Graduação em Enfermagem, Medicina e Nutrição. 2001 [acesso em 2015 nov 28]. Disponível em: <http://portal.mec.gov.br/cne/ arquivos/pdf/2001/pces1133 01.pdf>

6. Chaves LDP, Laus AM, Camelo SH. Ações gerenciais e assistenciais do enfermeiro em unidade de terapia intensiva. Ver Eletr Enfer (Internet) 2012 [acesso em 2015 nov 28]; n. 14, v. 3, p. 671-678. Disponível em: <https://www.fen.ufg.br/fen revista/ v14/n3/pdf/v14n3a25.pdf >

7. Christovam BP, Porto IS, Oliveira DC. Gerência do cuidado de enfermagem em cenários hospitalares: a construção de um conceito. Ver Esc Enferm USP 2012 [acesso em 2015 nov 28]; n.46, v. 3, p. 734-741. Disponível em: <http://www.scielo.br/ $\mathrm{pdf} / \mathrm{reeusp} / \mathrm{v} 46 \mathrm{n} 3 / 28 . \mathrm{pdf}>$.
8. Montezelli JH, Peres AM, Bernardino E. Demandas institucionais e demandas do cuidado no gerenciamento de enfermeiros em um pronto socorro. Ver Bras Enferm 2011 [acesso em 2015 nov 28]; n. 64, v. 2, p. 348-54. Disponível em: <http://www.scielo. br/pdf/reben/v64n2/a20v64n2.pdf>.

9. Santos JLG, Pestana AL, Guerrero P, Meirelles BSH, Erdmann AL. Práticas de enfermeiros na gerência do cuidado em enfermagem e saúde: revisão integrativa. Ver Bras Enferm 2013 [acesso em 2015 nov 27]; n.66, v. 2, p. 257-263. Disponível em: $<$ http://www.scielo.br/pdf/reben/v66n2/16.pdf $>$.

10. Oliveira RS, Azevedo NM, Albuquerque WG, Andrade M, Santo FHE. Gerência de um centro de atenção integral à saúde do idoso. R Em ferm Cent O Min 2011 [acesso em 2015 nov 27]; n. 1, v. 1, p. 131-135. Disponível em: <http://www.seer.ufsj.edu.br/ index.php/recom/article/viewArticle/16>.

11. Weirich CF; Munari DB, Mishima SM, Bezerra ALQ. O trabalho gerencial do enfermeiro na Rede Básica de Saúde. Rev. Texto Contexto Enferm 2009 [acesso em 2015 set 02]; n. 18, n. 2, p. 249-257. Disponível em: <http://www.scielo.br/pdf/tce/ v18n2/07.pdf>

12. Mendes KDS, Silveira RCCP, Galvão CM. Revisão integrativa: método de pesquisa para a incorporação de evidências na saúde e na enfermagem. Texto contexto enferm 2008 [acesso em 2015 set 02]; n. 17, v. 4, p. 758-64. Disponível em: $\quad<$ http://www.scielo.br/scielo.php?script=sci arttext\&pid $=$ S0104-07072008000400018>.

13. Melnyk BM, Fineout-Overholt E. Evidence-based practice in nursing \& healthcare - A guide to best practice. Philadelphia: Lippincot Williams \& Wilkins; 2005. p.3-24.

14. Sol AA, Farrez R. Influencia de la Gestión del Cuidado en la calidad de la atención en salud. Rev Cuba Enferm 2010 [acesso em 2015 out 25]; n. 26, v. 2, p. 14-26. Disponível em: $<$ http://www.bvs.sld.cu/revistas/enf/vol26 2 10/enf03210.htm $>$.

15. Oliveira FEL, Fernandes SCA, Oliveira LL, Queiroz JC, Azevedo VRC. A gerência do enfermeiro na estratégia saúde da família. Rev Rene 2012 [acesso em 2015 out 25]; n. 13, v.4, p. 834-44. Disponível em: <http://www.bvs.sld.cu/revistas/enf/vol26_2_10/ enf03210.htm>.

16. Santos ASS, Miranda SMRC, organizadores. A enfermagem na gestão em atenção primária à saúde. Barueri: Manole; 2007.

17. Neto FRGX, Sampaio JJC. Análise do Processo de Trabalho dos Gerentes no Territorio da Estratégia Saúde da Família. Rev Gerenc Polit Salud 2012 [acesso em 2015 out 25]; n. 11, v. 22, p. 76-91. Disponível em: <http://rev gerenc polit salud.javeriana. edu.co/vol11_n_22/estudios_3.pdf>. 
18. Nauderer TM, Lima MAD. Nurses' practices at health basic units in a city in the south of Brazil. Rev Latino-Am. Enfermagem 2008 [acesso em 2015 nov 30]; n. 16, v.5, p. 889-894. Disponível em:<http://www.scielo.br/pdf/rlae/v16n5/15.pdf>

19. Bray $P$, Cummings DM, Morrissey $S$, Thompson D, Holbert $D$, Wilson K, Lukosius E, Tanenberg R. Improved outcomes in diabetes care for rural africanamericans. Ann Fam Med2013 [acesso em 2015 nov 30]; n.11, v. 2, p.145-50. Disponível em: $<$ http://www.annfammed.org/content/11/2/145.full>

20. Rastegari M, Dehkordi AJ, Sabouhi F, GhalrizP. Assessing the effect of community health nursing care management at home on war-worn soldiers' physical problems suffering from spinal cord complications (urinary infection, bedsore). Iran j nurs midwifery res 2010 [acessado em 2015 nov 30];n. 15, v. 1, p. 322-330. Disponível em: <http://www.ncbi.n/m.nih.gov/pmc/ articles/PMC3208931/>.

21. Fernandes MC, Barros AS, Silva LMS, Nóbrega MFB, Silva MRF, Torres RAM. Análise da atuação do enfermeiro na gerência de unidades básicas de saúde. Rev. brasenferm 2010. [acessado em 2016 jan 20]; n. 63, v. 1, p. 11-15. Disponível em: $\quad<$ http://www.scielo.br/scielo.php?script=sci arttext\&pid $=$ S0034-71672010000100002>

22. Junior ARF, Vieira LJES, Barros NF. Entrevista con gestores como método pedagógico para la gerencia en enfermería: conocer para ser. Enfermglob 2012 [acessado em 2015 dez15]; n. 11, v. 2, p. 106-114. Disponível em: <http://revistas.um.es/eglobal/ article/view/137201>

23. Peres AM, Freitas LJ, Calixto RC, Martinez RJR, Sanjuan QA. Concepções dos enfermeiros sobre planeamento, organização e gestão de enfermagem na atenção básica: revisão integrativa. Rev Enf Ref 2013 [acessado em 2015 dez 15]; n. 3, v. 10, p. 153-160. Disponível em: <http://www.scielo.mec.pt/scielo. php?script=sci arttext\&pid=S0874-02832013000200018 $>$.

24. Diaz VB, Aguilar SC, Bernal ZR, Canellas DH. Gestión del cuidado desde una perspectiva transcultural. Rev Cuba Enferm 2011 [acessado em 2015 dez 15]; n. 27, v. 1, p. 57-65. Disponível em: http://scielo.sld.cu/scielo.php?script=sci_arttext \&pid=S0864-03192011000100007.
25. Aguero SE, Klijn TP. Enfermería en el rol de gestora de los cuidados. Ciencenferm 2010 [acessado em 2015 dez 15]; n. 16, v. 3, p.33-39. Disponível em: <http://www.scielo.cl/scielo. php?script=sci arttext\&pid=S0717-95532010000300005>

26. Spagnuolo RS, Juliani CMCM, Spiri WC, Bocchi SCM, Martins STF. O enfermeiro e a Estratégia Saúde da Família: desafios em coordenar a equipe multiprofissional. Ciência, cuidado e saúde 2012 [acessado em 2015 dez 17]; n. 11, v. 2, p. 226-34. Disponível em: <http://www.periodicos.uem.br/ojs/index.php/ CiencCuidSaude/article/view/10445>

27. Matumoto S, Fortuna CM, Kawata LS, Mishima SM, Pereira MJB. A prática clínica do enfermeiro na atenção básica: um processo em construção. Rev Latino-Am. Enfermagem 2011 [acessado em 2015 dez 20]; n. 19, v. 1, p. 123-130. Disponível em: $<$ http://www.scielo.br/pdf/rlae/v19n1/pt 17.pdf>

28. Aitamaa E, Leino-Kilpi H, Puukka P, Suhonen R. Ethical Problems in Nursing Management: The role of codes of Ethics. Nurs Ethics 2010 [acessado em 2015 dez 17]; p.17: 469. Disponível em: <http://www.ncbi.n/m.nih.gov/pubmed/20610580>.
Publish in International Archives of Medicine

International Archives of Medicine is an open access journal publishing articles encompassing all aspects of medical science and clinical practice. IAM is considered a megajournal with independent sections on all areas of medicine. IAM is a really international journal with authors and board members from all around the world. The journal is widely indexed and classified Q1 in category Medicine. 